\title{
Levrero, Mario.
}

O romance

luminoso. Tradução

de Antônio

Xerxenesky. São

Paulo: Companhia

das Letras, 2018,

$645 \mathrm{p}$.

Pedro Furtado

Recebido em: 29 de julho de 2020

Aceito em: 9 de setembro de 2020
Pedro Barbosa Rudge Furtado é doutorando pelo Programa de Pós-Graduação em Estudos Literários da Faculdade de Ciências e Letras de Araraquara (UNESP). Professor substituto de "Críticas Literárias" no curso de Letras da UNESP de Araraquara (2019 e 2020). Bolsista CAPES

Contato: pedro.sonata@smail.com Brasil 
Em 2013, a Editora Rocco iniciou o lançamento da coleção Otra lingua, dedicada à publicação de uma série de obras fulcrais da literatura latinoamericana não traduzidas para o português brasileiro. A primeira delas foi Deixa comigo, de Mario Levrero. Tal lançamento provocou a percepção, mediante o desfrute da engenhosidade espirituosa dessa narrativa meio noir, fantástica, filosófica e mítica, de que havia um enorme hiato editorial no Brasil, sobretudo - mas não somente - no embaraçoso desconhecimento da obra de Levrero. Passados cincos anos da primeira publicação do escritor uruguaio em terras brasileiras, a Companhia das Letras colocou no mercado $O$ romance luminoso, aparentemente, à primeira vista, nem romance nem luminoso.

Em termos formais, o título acentua a mínima parte de seu livro, isto é, o próprio "romance luminoso", que ocupa em torno de um quinto - a parte derradeira - da malha textual. O âmago da obra, no entanto, é a espécie de prólogo, em forma de diário da prostraçáo, em que o autor-narrador relata, escrevendo, a impossibilidade de retomar a escrita do "romance luminoso" e justificar a bolsa recebida pela Fundação Guggenheim que fomentaria a finalização da narrativa, iniciada nos idos anos de 1984. Contudo, a própria composição do diário, como uma amiga do protagonista revela ao ler alguns trechos, parece seguir a estrutura de um romance - essa forma historicamente amorfa que agrupa os mais variados gêneros textuais - "com um protagonista e situaçóes inventadas" por Levrero $(2018,416)$. Animado por esse comentário, Mario chama, com mais afinco após essa observação, o seu escrito de romance, realçando a sua organização meio ficcional, 
especialmente na seleção de atos a serem narrados e na fantasia embutida neles, que edificam, de fato, uma certa unidade romanesca.

De qualquer forma, a tensão entre sinais ficcionais e reais faz parte da poética de Levrero, que nunca a escondeu. Digamos que o diário é a estruturabase que fundamenta, neste caso, um tipo de triagem romanesca e imaginativa dos fatos. O diário romanceado, para o autor, figura "o testemunho de um grande fracasso" (Levrero, 2018, 18) tanto devido à inconclusão da história luminosa quanto pela opacidade da iluminação ao ser narrada ao sabor da trivialidade do cotidiano. Ora, seria um real contrassenso indicar a luminosidade do diário romanceado? Acreditamos que não. Inserida na exposição da rotina - muitas vezes soturna, solitária e melancólica - encetada na forma maleável do diário, ressoam ilhas de brilho (em contraposição à inflexão lúgubre de parte do relato) que promovem a vontade de viver do protagonista, embora ele conviva com a aura da morte à espreita.

Segundo Marcello Duarte Mathias $(1997,45)$, há afinidade entre a escrita diarística, no fechamento de cada entrada, e a morte do ser. O diário constitui "mil e uma breves autobiografias, sempre repetidas e inacabadas", sendo, por conseguinte, autobiografias em eterno desenvolvimento, náo oferecendo o aperfeiçoamento de um relato terminado. Como contraponto, essa forma ostenta a particularidade de dar o efeito de contínuo acabamento por meio do inacabamento: mesmo quando interrompido pela morte do autor, o diário não parece mais incompleto do que sempre foi.

Se geralmente os diários aspiram à potencialidade do dia seguinte, o de Levrero, recortando - selecionando - um ano de sua vida (de agosto de 
2000 ao mesmo mês de 2001), enfrenta diversas perdas do outro, sejam elas literais, fantasiosas e/ou simbólicas, que o lançam para o passado em que o outro era vivo, presentificando, por outro lado, no nível psíquico e material da elaboração do diário, o confronto com a ausência. Entre os óbitos literais, há os de amigos, como Magro, Ruben (que hospedou o protagonista após o seu divórcio), Tuli e Jorge. A cada um deles apreendemos o desenvolvimento do luto do narrador no devir da absorção da fatalidade normalmente tratada na solidão das suas páginas. Acerca do falecimento de Ruben, que sintetiza o comportamento de Mario no que se refere aos outros, ele diz, cinco ou seis dias passados, que a morte continua sendo processada muito, "mas muito lentamente, enquanto eu me abstenho de ações necessárias tais como ir ao velório e ao enterro e participar socialmente dessas coisas que por algum motivo inventaram" (Levrero, 2018, 322).

Há uma correspondência entre o ritmo dos diversos lutos do protagonista, deslindado no decorrer do diário, e a expressão obsessora da não decomposição do cadáver de uma pomba - o luto fantasioso-simbólico. O corpo surge, no teto do prédio vizinho, no dia 25 de setembro de 2000 e é retomado, como motivo de elucubração, a cada visão do narrador, quando abertas as persianas de seu apartamento, até o epílogo do diário. A pomba morta, nesse olhar da paisagem solitária do protagonista de dentro para fora, pode representar, segundo Mario, o seu espírito inerte que ninguém "poderá ressuscitar apesar de todos os seus esforços" (Levrero, 2018, 227).

Se, a priori, a presença do cadáver pode náo ser questionada pelo leitor, no andamento do texto ela é colocada em xeque à medida que o corpo persiste 
intocado e íntegro apesar do tempo decorrido, que fatalmente o deterioraria. Embora o narrador constate algumas vezes a deformação do cadáver, o próprio deformar-se e o ressurgimento constante, às vezes revigorado, da imagem pútrida parecem mais a projeção da lógica interna de uma mente altamente imaginativa - que deseja enxergar a ruína - do que um objeto real.

Pari passu, a narrativa é cercada por uma outra ausência de algo que nunca participou, de fato, a não ser a partir de pequenas rememoraçóes, da história: a sexual. A abstinência decorre do tratamento terapêutico pelo qual Chl - a única personagem cujo nome real é omitido até o final do livro passa. Antes parceiros sexuais, $\mathrm{Chl}$ decide não mais transar com Mario a partir do momento em que, com a ajuda da psicanálise, avista uma melhora do seu quadro psicológico na interdição do ato.

Dessa forma, engendram-se na mente do protagonista duas vontades incompatíveis: a de retomar a relação, o que figuraria o fracasso da terapia de mulher, e a esperança de que $\mathrm{Chl}$ progrida, o que a afugentaria ainda mais dele, não apenas sexualmente, mas de modo todo físico ao não acompanhá-lo em passeios ou preparar-lhe ensopados e bifes à milanesa - em uma relação de certo cuidado maternal dela para com ele. O paulatino desligamento de Chl do protagonista começara um ano antes da composição do diário, mais precisamente na viagem em que ela afastou-se, pela primeira vez, de Mario. Fruto dessa "viagem fatídica” (Levrero, 2018, 54) e do conseguinte insulamento do narrador, ele guarda resquícios de uma severa tristeza que o prostrou durante meses. O inaugural distanciamento de Chl é retomado diversas vezes, figurando outro sinal de privação do amor na série de motivos 
fantasmagóricos do romance - juntamente com a morte dos amigos e a compulsiva atração pelo cadáver da pomba.

Todavia, em concomitância com os signos da ausência do outro, acompanhamos a elaboraçáo de estratégias de autodefesa do eu-narrador - em algo análogo ao processo de sublimação - com o intuito, mesmo inconsciente, de reorganizar o seu equilíbrio psíquico. Sublimar significa defender-se da pulsão de morte através do desvio do sofrimento para uma atividade que consiga substituir o outro (Birman, 2008, 20). Assim, Mario empenha-se, com toques maníacos, na renovaçáo do seu apartamento, na instalaçáo e desinstalação de softwares, na produçáo repetitiva de iogurte, na leitura aficionada de romances policiais (alguns bastante ruins, de acordo com ele), na tentativa de conseguir outras companhias (sempre femininas) de passeio, uma vez que o protagonista não sai sozinho de casa etc. A inflexão às vezes humorística do relato também funciona como amortecedor do desânimo.

Derivado do afă de proteção do eu, ele luta contra o tempo externo das convenções, perdendo-se no ritmo interno da compulsão - o narrador, consciente, confessa: "[...] tudo o que faço é de forma compulsiva; sou uma pilha de compulsóes. Não me resta um átomo de força de vontade" (Levrero, 2018, 503). A rotina de passar madrugadas em claro e acordar às quatro da tarde, então, isola mais fortemente Mario no apartamento, separando-o de outras pessoas - ditadas por outra temporalidade - e concebendo como desafiadores atos corriqueiros, como ir ao dentista, a instituiçóes públicas etc. 
$\mathrm{Na}$ esteira da disposição sublimatório-maníaca, que muitas vezes perturba o narrador nessa temporalidade errática, Freud (2019, 112), de quem Mario parece não gostar, afirma que um dos destinos do melancólico é alternar-se entre os estados de grave tristeza, deploraçáo de si, prostração, subsumidos e emanados pela falta do objeto amoroso, e as situaçôes de júbilo, alegria e triunfo da mania, em que o sujeito está consumido por uma sede poderosa de ligar-se ao outro, de encobrir freneticamente a falta do ausente. A mania, assim, seria ilusória no sentido de que o luto não foi completado, servindo tão somente como condição passageira do mal-estar.

Entretanto, seja no recorte estabelecido na construção do diário ou durante parte da vida de Mario, é possível dizer que a mania, se não vence a melancolia devido à imanência de uma na outra, triunfa ligeiramente sobre a profunda tristeza no sentido de dar à existência do protagonista um desejo de futuro, náo o lamentar-se infindável nem a ânsia suicida do melancólico. Em tal caldo conflitivo de pulsôes há, para nós, o subtexto luminoso advindo da estruturação das políticas de sofrimento de Levrero.

O impulso para frente, disposto em entradas e excertos isolados do diário, é explicitado, de forma mais clara, no momento em que o narrador procura uma maneira de arrematar os registros. Ele ensaia um fim trágico em que fossem acentuadas as marcas do seu fracasso e o dramático sentimento de vazio niilista que o ronda. Nessa modulação sombria, o livro poderia "vender muito bem". No entanto, ele rechaça tanto a sede financeira quanto a pulsão de morte: 


\begin{abstract}
Mas não tenho interesse em vender livros; nunca tive. E, para piorar, não é verdade que estou cansado de viver. Poderia continuar levando exatamente esse tipo de vida que estou levando agora durante todo o tempo que o bom Senhor queira me outorgar, inclusive de forma indefinida. Se é verdade que alguns dos meus comportamentos me incomodam, também é verdade que não me esforço demais para modificá-los. Na verdade sou feliz, estou cômodo, estou contente, embora dentro de certo dominio depressivo (Levrero, 2018, 495, grifo nosso).
\end{abstract}

Altamente consciente de sua situação, Mario, dentro dos afetos possíveis irradiados pela melancolia, afirma-se apto a viver no interior da tristeza que o abarca, encontrando, nela, a luz que entrevê o porvir. A falta do objeto de desejo e a solidão do protagonista não limitam uma visão de futuro como campo de possibilidades, embora a morte o circunde. Se a depressão oferecelhe, diante de tantos lutos, a morte também como possibilidade, o óbito dos outros, ao ser enfrentado, faz perdurar a pulsão de vida. Essa dualidade conflituosa é sintetizada nas últimas linhas da obra quando o protagonista, olhando pela sua janela em direção ao prédio vizinho, enxerga, ao mesmo tempo que sente que a visão pode enganá-lo (a morte e a vida fundidas na existência ou não do cadáver), o corpo da pomba morta, expressão funesta de uma mente fantasiosa - do falecimento global que rodeia a narrativa: "A paisagem agora está limpa como antes. A caveira da pomba parece continuar no seu lugar; já não vejo mais os ossinhos do seu corpo, mas talvez estejam lá, sim” (Levrero, 2018, 645).

Há, inseridos nas vontades tensionadas de Mario, outros tantos fragmentos dignos de leitura atenta, como as persistentes descriçôes de sonhos, a conexão telepática que ele acredita ter com o dono da banca de livros - dois dados 
que complementam a atmosfera onírico-mítica e psicanalítica romanceada da obra -, a relação estranha com a ex-mulher, também sua médica. Enfim, no interior de romance tão denso e multivalente, destacamos como o ambiente regido pelos signos da morte pode, em boas mãos, ser convertido - ou reorientado - de modo arguto e, através das próprias alternativas da tristeza, em pulsão luminosa de vida mediante a fantasia, a sublimação e outras estratégias de proteção do eu.

\section{REFERÊNCIAS BIBLIOGRÁFICAS}

Birman, Joel. "Criatividade e sublimação em Psicanálise". In: Psicologia Clínica. Rio de Janeiro, v. 20, n. 1, 2008, 11-26.

Freud, Sigmund. "Luto e melancolia". In: Freud, Sigmund. Neurose, psicose, perversão. Tradução de Maria Rita Salzano Moraes. Belo Horizonte: Autêntica Editora, 2019, 99-121.

Mathias, Marcello Duarte. "Autobiografias e diários". In: Colóquio: Revista de Artes e Letras. Lisboa, n. 143-144, 1997, 41-62. 